\title{
Thermophilic bacteria isolated from Mount Merapi, Java, Indonesia as a potential lead bioremediation agent
}

\author{
ANNA RAKHMAWATI ${ }^{1,2, v}$, ENDANG TRI WAHYUNI ${ }^{1,3}$, TRIWIBOWO YUWONO ${ }^{1,4, v \vee}$ \\ ${ }^{1}$ Program of Biotechnology, Graduate School, Universitas Gadjah Mada. Jl. Teknika Utara, Barek, Sleman 55281, Yogyakarta, Indonesia \\ ${ }^{2}$ Department of Biology Education, Faculty of Mathematics and Natural Sciences, Universitas Negeri Yogyakarta. Jl. Colombo 1, Karangmalang, Sleman \\ 55281, Yogyakarta, Indonesia. Tel.: +62-274-586168, Fax.: +62-274-548203,"email: anna_rakhmawati@uny.ac.id \\ ${ }^{3}$ Department of Chemistry, Faculty of Mathematics and Natural Sciences, Universitas Gadjah Mada. J1. Sekip Utara, Bulaksumur, Sleman 55281, \\ Yogyakarta, Indonesia \\ ${ }^{4}$ Department of Agricultural Microbiology, Faculty of Agriculture, Universitas Gadjah Mada. J1. Flora, Bulaksumur, Sleman 55281, Yogyakarta, \\ Indonesia. Tel.: +62-274-564305; Fax.: +62-274-520842, ^^email: triwibowo_y@ugm.ac.id
}

Manuscript received: 17 March 2021. Revision accepted: 9 May 2021.

\begin{abstract}
Rakhmawati A, Wahyuni ET, Yuwono T. 2021. Thermophilic bacteria isolated from Mount Merapi, Java, Indonesia as a potential lead bioremediation agent. Biodiversitas 22: 3101-3110. Contamination by lead $(\mathrm{Pb})$ has become a serious health and environmental problem, that has to be urgently prevented. Bioremediation is one of the environmentally friendly methods for eliminating $\mathrm{Pb}$ from the contaminated environment. This study was aimed to investigate the potency of lead-tolerant thermophilic bacteria isolated from solfatara Mount Merapi, Indonesia. A total of 340 isolates of thermophilic bacteria were screened for lead tolerance at $55{ }^{\circ} \mathrm{C}$. Five bacterial isolates were found to show tolerance to $100 \mathrm{mg} / \mathrm{L} \mathrm{Pb}$ (II), and then were further evaluated and identified as Aeribacillus pallidus strains MRP112, MRP148, MRP272, MRP278, and MRP280 based on 16S rRNA gene sequences analysis. Among the five isolates, A. pallidus MRP 280 showed highest activity in removing $\mathrm{Pb}$ at $\mathrm{pH} 6,55^{\circ} \mathrm{C}$ for $24 \mathrm{~h}$. The analysis of scanning and transmission electron microscopy, biofilm formation, and siderophore production, demonstrated that lead tolerance of $A$. pallidus MRP 280 strain was also accompanied by morphological changes, bioaccumulation, biosorption, biofilm, and siderophore assembly. In conclusion A. pallidus MRP 280 was demonstrated as one of the most potential bacterial strains, can be recommended as an agent for high-temperature lead bioremediation.
\end{abstract}

Keywords: Aeribacillus pallidus, biosorption, lead tolerance, thermophilic bacteria

\section{INTRODUCTION}

Lead $(\mathrm{Pb})$ has been regarded as one of the most hazardous heavy metal pollutants. Geogenic and anthropogenic activities are the lead sources in the environment. The smaller levels of lead are hazardous to people's health, the physiological role of lead in the organism has not been well known. Lead is also highly persistent and accumulated, thus it becomes a serious environmental problem (Wani et al. 2015, Vigneri et al. 2017, Kushwaha et al. 2018).

Several techniques such as chemical precipitation (Akinterinwa and Adibayo 2018), electrocoagulation (Abbas and Ali 2018), adsorption (Ghasemi et al. 2014), ion exchange (Bezzina et al. 2019), and membrane filtration (Wang et al. 2018) have been implemented for removal of lead However, these technologies have many limitations such as high cost for energy and maintenance, and the emergence of toxic byproducts. On the other hand, biological agents such as microorganisms offer easy, ecofriendly, cost-effective, and efficient methods for $\mathrm{Pb}$ remediation (Gupta and Joia 2016; Ayangbenro and Babalola 2017; Jacob et al. 2018; Sharma et al. 2018). Therefore, microbe-based approaches have several advantages over traditional physical and chemical methods including (i) higher specificity, (ii) suitability for in situ techniques, and (iii) potential for improvement by genetic engineering (Tiquia 2018).

Lead tolerant bacteria used as $\mathrm{Pb}$ bioremediation agents are urgently required. In general, bacteria that are tolerant to toxic metals have extreme properties such as tolerance to high temperatures up to $75^{\circ} \mathrm{C}$. Multiple lead tolerant thermophilic bacterial species have been identified from various parts of the world such as Geobacillus thermodenitrificans (Chatterjee et al. 2010), G. thermodenitrificans and G. thermocatenulatus (Babák et al. 2012), Stenotrophomonas maltophilia, Aeromonas veronii, and Bacillus barbaricus (Sen et al. 2014), Thermus thermophilus (Nicolaus et al. 2016), G. galactosidasius sp (Özdemir et al. 2016); Pseudomonas sp. (Kalita and Joshi 2017), and B. stearothermophilus (Al-Khafaji et al. 2018).

This study focused on characterization of lead-tolerant thermophilic bacteria isolated from volcano mud of Merapi, Indonesia. The selected isolates that demonstrated tolerance to high concentrations of $\mathrm{Pb}$ were further investigated to determine the Minimum Inhibitory Concentration (MIC), $\mathrm{Pb}$ removal ability, growth profile, and $\mathrm{Pb}$ tolerance mechanisms. Biofilm formation, siderophore production, Transmission Electron Microscopy (TEM), Scanning Electron Microscopy (SEM), Fourier Transform Infra-Red spectroscopy (FTIR), and Atomic Absorption Spectroscopy (AAS), as well as analysis of 
ability to detoxify $\mathrm{Pb}$ were used for characterization of the selected isolates. The present results, thus, are promising to be a foundation to develop a method of bioremediation at high temperatures by using indigenous microorganisms.

\section{MATERIALS AND METHODS}

\section{Bacterial strain, media, and chemicals}

Thermophilic bacteria were originally isolated from solfatara of volcano Mount Merapi at Gendol Atas River, Indonesia $\left(7^{\circ} 39^{\prime} 20.1^{\prime \prime S} 110^{\circ} 27^{\prime} 49.9^{\prime \prime} \mathrm{E}\right)$. The bacterial isolates were deposited in Laboratory of Microbiology, Department of Biology Education, Faculty of Mathematics and Natural Sciences, Universitas Negeri Yogyakarta, Indonesia. All media and chemicals used in the study were of analytical grade. Luria Bertani (LB) was prepared by using following composition $(\mathrm{g} / \mathrm{L})$ : tryptone 10 , yeast extract 5 , and $\mathrm{NaCl} 10$, and agar 15 to prepare agar plate. Stock solutions of $\mathrm{Pb}$ (II) $(1000 \mathrm{mg} / \mathrm{L})$ were prepared by dissolving $\mathrm{Pb}\left(\mathrm{NO}_{3}\right)_{2}$ in aquabidest and $1 \mathrm{~mL} / \mathrm{L}$ of 0.1 $\mathrm{mol} / \mathrm{L} \mathrm{HNO}_{3}$ was added to the solutions to prevent the precipitation of $\mathrm{Pb}(\mathrm{II})$ by hydrolysis. All glassware used during the $\mathrm{Pb}$ (II) analysis were washed in $30 \% \mathrm{HNO}_{3}$ and rinsed several times in aquabidest prior to use.

The medium used for screening was a solution containing $\mathrm{NaCl}$ at $5 \mathrm{~g} / \mathrm{L}$ concentration to prevent $\mathrm{PbCl}_{2}$ precipitation as suggested by Peens et al. (2018). The LB media and $\mathrm{Pb}\left(\mathrm{NO}_{3}\right)_{2}$ stock solution were autoclaved at 121 ${ }^{\circ} \mathrm{C}$ for 15 minutes separately.

\section{Screening of lead-tolerant bacteria}

The lead tolerance assay was performed by streak plate method as reported by Chaudhary et al. (2017). Luria Bertani (LB) agar medium was supplemented with 25, 50, 75, and $100 \mathrm{mg} / \mathrm{L}$ of $\mathrm{Pb}\left(\mathrm{NO}_{3}\right)_{2}$ at $\mathrm{pH}$ 7. Duplicated plates were prepared for each $\mathrm{Pb}$ concentration and incubated at $55{ }^{\circ} \mathrm{C}$ for $72 \mathrm{~h}$. Each plate was checked for the appearance of visible growth which indicated the tolerance towards $\mathrm{Pb}$ is present in the medium. Several bacterial strains that demonstrated tolerance up to $100 \mathrm{mg} / \mathrm{L}$ of $\mathrm{Pb}$ were further investigated.

\section{Bacterial identification using 16S rRNA}

The selected lead-tolerant bacterial isolates were identified by using $16 \mathrm{~S}$ rRNA sequencing technique (Kumar et al. 2018; Penaloza-Vazquez et al. 2019). The bacterial isolates were cultured in LB broth in $100 \mathrm{r} / \mathrm{min}$ shaking incubator at $55{ }^{\circ} \mathrm{C}$ for $24 \mathrm{~h}$. Bacterial cells were harvested and genomic DNA was extracted using QuickDNA $^{\mathrm{TM}}$ Fungal/Bacterial Miniprep Kit (Zymo Research, D6005). The 16S rDNA amplification was carried out by using universal bacterial primers MRPs 27F (5'AGAGTTTGATCCTGGCTCAG-3') and 1492 R (5'TACGGTTACCCTTACGACTT-3') and amplified with MyTaq HS Red Mix (Bioline, BIO-25047). The amplification cycle was as follows: an initial denaturation step at $95{ }^{\circ} \mathrm{C}$ for $1 \mathrm{~min} ; 35$ cycles of denaturation at $95{ }^{\circ} \mathrm{C}$ for $15 \mathrm{~s}$, annealing at $52{ }^{\circ} \mathrm{C}$ for $15 \mathrm{~s}$, and extension at $68^{\circ} \mathrm{C}$ for $45 \mathrm{~s}$. The amplification product was then purified by using Zymoclean Gel DNA Recovery Kit (Zymo Research) for sequencing. Sequence analysis was carried out by comparing with the Gene Bank database using BLASTn program (http://www.ncbi.nlm.nih.gov/BLAST) using nearest neighbor of sequences method. In addition, Mega X software was used to construct a phylogenetic tree based on $16 \mathrm{~S}$ rDNA of selected bacterial isolates.

\section{Minimum Inhibitory Concentration}

The selected bacterial strains were also tested for their Minimal Inhibitory Concentration (MIC). In the present study, both solid and liquid media were used to determine the MIC and metal mobility (bioavailability) of those bacterial strains. The combined approach gave a better understanding of exact concentration of metals that inhibit bacterial growth (Neethu et al. 2015). The MICs to $\mathrm{Pb}(\mathrm{II})$ for a series of concentrations $(0,25,50,75,100,125$, and $150 \mathrm{mg} / \mathrm{L}$ ) were tested both in LB broth and LB agar for 24 h. Cultures with an $\mathrm{OD}_{600}$ of 0.8 , were inoculated into medium solutions for each treatment, in triplicates. Bacterial cultures were incubated at $55{ }^{\circ} \mathrm{C}$ for $24 \mathrm{~h}$, with agitation at $100 \mathrm{r} / \mathrm{min}$. Bacterial growth was measured by using spectrophotometric method at $\mathrm{OD}_{600}$. LB culture medium without $\mathrm{Pb}$ addition was used as positive control, while the non-inoculated LB culture medium was used as negative control.

\section{Pb removal assay}

The $\mathrm{Pb}$ removal assay on five selected strains was carried out according to a modified protocol of $\mathrm{Li}$ et al. (2013) and Abdi and Kazemi (2015). The isolates were firstly cultivated at least for $24 \mathrm{~h}$ to be used as inoculum. Three $100 \mathrm{~mL}$ Erlenmeyer flasks containing $30 \mathrm{~mL}$ of autoclaved LB medium were inoculated with $3 \mathrm{~mL}\left(\mathrm{OD}_{600}\right.$ 0.8 ) of inoculum and supplemented with $100 \mathrm{mg} / \mathrm{L}$ of $\mathrm{Pb}$. Cultures were then incubated at $55^{\circ} \mathrm{C} \mathrm{pH} \mathrm{5,} \mathrm{6,} \mathrm{and} 7$ under $100 \mathrm{r} / \mathrm{min}$ for $24 \mathrm{~h}$. LB media supplemented with corresponding concentrations of $\mathrm{Pb}$ in each treatment was used as the blank control. Following the removal of bacterial cells by centrifugation at $5000 \mathrm{r} / \mathrm{min}$ for $10 \mathrm{~min}$, supernatant was collected and $\mathrm{Pb}$ concentration was measured using atomic absorption spectrophotometer (AAS 7000, Shimadzu, Japan). In addition, lead removal rate $(\mathrm{R})$ was calculated by using the following formula (Jiang et al. 2016):

$$
\mathrm{R}=\left(1-\mathrm{C} / \mathrm{C}_{0}\right) \times 100 \%
$$

Where; $\mathrm{R}, \mathrm{C}$, and $\mathrm{Co}$ are $\mathrm{Pb}$ removal rate $(\%)$, final $\mathrm{Pb}$ concentration $(\mathrm{mg} / \mathrm{L})$, and initial $\mathrm{Pb}$ concentration $(\mathrm{mg} / \mathrm{L})$, respectively.

\section{Biofilm formation}

Evaluation of biofilm formation at different $\mathrm{Pb}$ concentrations $(0,25,50,75$, and $100 \mathrm{mg} / \mathrm{L})$ by five isolates was performed by using the protocol of Giovanella et al. (2017) with modification. The bacterial isolates were grown in $200 \mu \mathrm{L} \mathrm{LB}$ with various concentrations of $\mathrm{Pb}$ at $55^{\circ} \mathrm{C}$ and $\mathrm{pH} 7$ without agitation. After $72 \mathrm{~h}$ of incubation, the culture medium was aspirated and washed three times 
with $250 \mu \mathrm{L}$ of $0.9 \% \mathrm{NaCl}$ solution and left to dry at $40{ }^{\circ} \mathrm{C}$ for $40 \mathrm{~min}$. The adhered cells were dyed with $1 \%$ gentian violet for $10 \mathrm{~min}$ and the excess dye was removed. The biofilm was washed with $0.9 \% \mathrm{NaCl}$ solution five times and lastly washed with $95 \%$ ethanol. The biofilm was quantified by reading the absorbance using an ultravioletvisible spectrophotometer GENESYS 10S (ThermoFisher Scientific) at $595 \mathrm{~nm}$. Non-inoculated LB culture medium was used as negative control, while LB culture medium without metals was used as positive control.

\section{Siderophores production}

The selected five isolates were evaluated for siderophore production after $24 \mathrm{~h}$ of incubation at $55^{\circ} \mathrm{C}$ and at $\mathrm{pH}$ 7. The bacterial cells were prepared following the procedure as previously described by Arora and Verma (2017) and Giovanella et al. (2017) with some modifications. LB medium was used to quantify siderophore production with the addition of $0,25,50,75$, and $100 \mathrm{mg} / \mathrm{L}$ of $\mathrm{Pb}$. The positive control was the inoculated nutrient broth without $\mathrm{Pb}$ addition and the negative control was uninoculated nutrient broth without $\mathrm{Pb}$ addition.

Quantitative siderophore production was determined by CAS assay (Schwyn and Neilands 1987) with modifications. The chromeazurol S (CAS) solution was prepared as follows: six mL $10 \mathrm{mM}$ HDTMA was added to a $100 \mathrm{~mL}$ volumetric flask and diluted with ultrapure water. A mixture of $1.5 \mathrm{~mL}$ iron III $\left(1 \mathrm{mM} \mathrm{Fe}_{3} \mathrm{Cl}_{3}\right.$ in $\left.10 \mathrm{mM} \mathrm{HCl}\right)$ and $7.5 \mathrm{~mL}$ CAS solution were then added to the flask. Anhydrous piperazine (4.307 g) was dissolved in ultrapure water. This solution (at $\mathrm{pH}$ 5.6) was added to the volumetric flask to complete the $100 \mathrm{~mL}$.

Two $\mathrm{mL}$ aliquots of the culture were centrifuged at $10,000 \mathrm{r} / \mathrm{min}$ for $10 \mathrm{~min}$, and $1 \mathrm{~mL}$ of the supernatant was then removed prior to the addition of $1 \mathrm{~mL}$ of the CAS solution. After $10 \mathrm{~min}$ of incubation at room temperature, the absorbance was read using a UV-Vis spectrophotometer GENESYS 10S (ThermoFisher Scientific) at $630 \mathrm{~nm}$. Culture medium without the addition of metals was used as the blank. Siderophore production was calculated as follows: A- $\mathrm{Ab}(\mathrm{A}=\mathrm{absorbance}$ of the sample; $\mathrm{Ab}=\mathrm{absorbance}$ of the blank).

\section{Growth profile of Aeribacillus pallidus MRP280}

Aeribacillus pallidus MRP280 that showed the highest activity in removing $\mathrm{Pb}$, biofilm, and siderophore assembly was further investigated. A. pallidus MRP280 growth profile was determined by measuring the cell density at $\mathrm{OD}_{600}$ every 3 hours for $48 \mathrm{~h}$ at $55^{\circ} \mathrm{C}$ under different $\mathrm{Pb}$ concentrations $(0,50,100 \mathrm{mg} / \mathrm{L})$ and $\mathrm{pH}(5,6,7)$. All experiments were carried out using LB media and bacterial inoculum size of $\mathrm{OD}_{600} 0.8$ in a shaking incubator at 100 $\mathrm{r} / \mathrm{min}$.

\section{Bioaccumulation and biosorption assay}

Lead bioaccumulation and biosorption assay in bacterial cell was conducted on A. pallidus MRP 280 strain with the highest level of $\mathrm{Pb}$ removal, biofilm formation, and siderophore synthesis, following the assay procedure of
Bai et al. (2014) with some modifications. After $\mathrm{Pb}$ removal experiment conducted at $100 \mathrm{mg} / \mathrm{L} \mathrm{pH} 6$ for $24 \mathrm{~h}$, the A. pallidus MRP 280 suspension was centrifuged and the biomass was resuspended in one of three desorption reagents: milli-Q water, $1.0 \mathrm{~mol} / \mathrm{L} \mathrm{NH}_{4} \mathrm{NO}_{3}$ (AR grade, Merck, Germany) or $0.1 \mathrm{~mol} / \mathrm{L}$ EDTA-Na 2 (AR grade, Merck, Germany). The suspension was centrifuged at 5000 $\mathrm{r} / \mathrm{min}$ for $10 \mathrm{~min}$. The $\mathrm{Pb}$ ion concentration in the supernatant was analyzed by the Atomic Absorption Spectrophotometer (AAS 7000, Shimadzu, Japan).

\section{Characterization of the $\mathbf{P b}$ bioprecipitates}

Lead $(\mathrm{Pb})$ bioprecipitation by A. pallidus MRP280 was investigated in media containing $100 \mathrm{mg} / \mathrm{L} \mathrm{Pb}$ after incubation up to mid-exponential phase $(15 \mathrm{~h})$. The characterization of the precipitates was carried out by Fourier Transform InfraRed (FTIR) spectroscopy, Scanning Electron Microscopy which were integrated with Energy Dispersive X-Ray (SEM-EDX), and Transmission Electron Microscopy (TEM).

\section{FTIR spectroscopy}

FTIR spectrum was obtained to describe the changes in the bacterial cell functional groups due to $\mathrm{Pb}$ precipitation. For FTIR analysis, the control and $\mathrm{Pb}$ treated cell biomass were centrifuged at $5000 \mathrm{r} / \mathrm{min}$ for $10 \mathrm{~min}$, washed three times with aquabidest, and the pellets obtained were then oven-dried at $80{ }^{\circ} \mathrm{C}$ overnight. Samples were prepared by diluting cell pellets to $5 \% \mathrm{KBr}$ and casting them in disks for FTIR spectroscope analysis (8201PC, Shimadzu, Japan).

\section{SEM-EDX analysis}

This analysis was performed to detect the cell surface morphology and elemental composition (Ren et al. 2015) of samples before and after applying $\mathrm{Pb}$. For SEM analysis, the control and $\mathrm{Pb}$-treated cell biomass was centrifuged at $5000 \mathrm{r} / \mathrm{min}$ for $10 \mathrm{~min}$, washed three times with aquabidest. The samples then were loaded pellets a copper grid coated with carbon onto these pellets for observation under SEMEDX (JSM-6510LA, Japan).

\section{TEM images observation}

Lead accumulation in bacterial cells was investigated by TEM based on Building (2010), with modification for sample preparation. Two $\mathrm{mL}$ aliquots of the culture were centrifuged for $3 \mathrm{~min}$ at $3000 \mathrm{r} / \mathrm{min}$, fixed in $2.5 \%$ glutaraldehyde (in $0.1 \mathrm{M}$ cacodylate buffer and $3 \%$ sucrose), and stored at $4{ }^{\circ} \mathrm{C}$ with shaking condition overnight. Next, the cells were centrifuged at $3000 \mathrm{r} / \mathrm{min}$ for $3 \mathrm{~min}$ and washed twice with $0.1 \mathrm{M}$ cacodylate buffer and $3 \%$ sucrose, followed by fixation in $2 \%$ osmium tetroxide, $2.5 \% \mathrm{~K}_{3} \mathrm{Fe}(\mathrm{CN})_{6}$, and $3 \%$ sucrose for $2 \mathrm{~h}$ at $4{ }^{\circ} \mathrm{C}$. The bacterial pellets were then washed three times with cacodylate buffer. A graded ethanol series $(10 \%, 50 \%$, $70 \%, 80 \%, 96 \%$, and $100 \%$ ethanol) were used to dehydrate the samples. After dehydration, the prepared biomass samples were infiltrated gradually with propylene oxide and immediately embedded in Spurr resin. Ultrathin sections of 50-100 nm thickness were cut using an 
ultramicrotome and taken on copper grids, and stained with uranyl acetate and triple lead before the observation under a transmission electron microscopy (JEM1010, JEOL, Japan).

\section{Statistical analysis}

Data for $\mathrm{Pb}$ removal, biofilm formation, and siderophore production for each selected bacterium were subjected to statistical analysis using SPSS 22.00 (IBM Corporation, Armonk, NY, USA). Mean variables were compared using Duncan's multiple range test (DMRT) with $\mathrm{p}<0.05$ was considered as significant data.

\section{RESULTS AND DISCUSSION}

\section{Lead-tolerant bacteria screening}

A total of 340 thermophilic bacteria have been isolated from solfatara Mount Merapi, Indonesia, which were then screened for lead tolerance. The numbers of bacterial isolates that demonstrated growth at 25; 50; 75; and 100 $\mathrm{mg} / \mathrm{L} \mathrm{Pb}$ were $140 ; 39 ; 12 ;$ and 5 respectively, demonstrating that only 5 bacterial isolates showed tolerance to a very high $\mathrm{Pb}$ concentration $(100 \mathrm{mg} / \mathrm{L})$. The five isolates, designated as isolates MRP112, MRP148, MRP272, MRP278, and MRP280 were further investigated (Table 1).

\section{Phylogenetic analysis}

The results of the phylogenetic analysis of MRP112, MRP148, MRP272, MRP278, and MRP280 on 16S rRNA gene sequences are displayed in Figure 1. It is clear that those five isolates belong to species Aeribacillus pallidus with $99-100 \%$ of identity. The $16 \mathrm{~S}$ rRNA gene sequences of these five isolates were then submitted to NCBI under these accession numbers (Table 1).

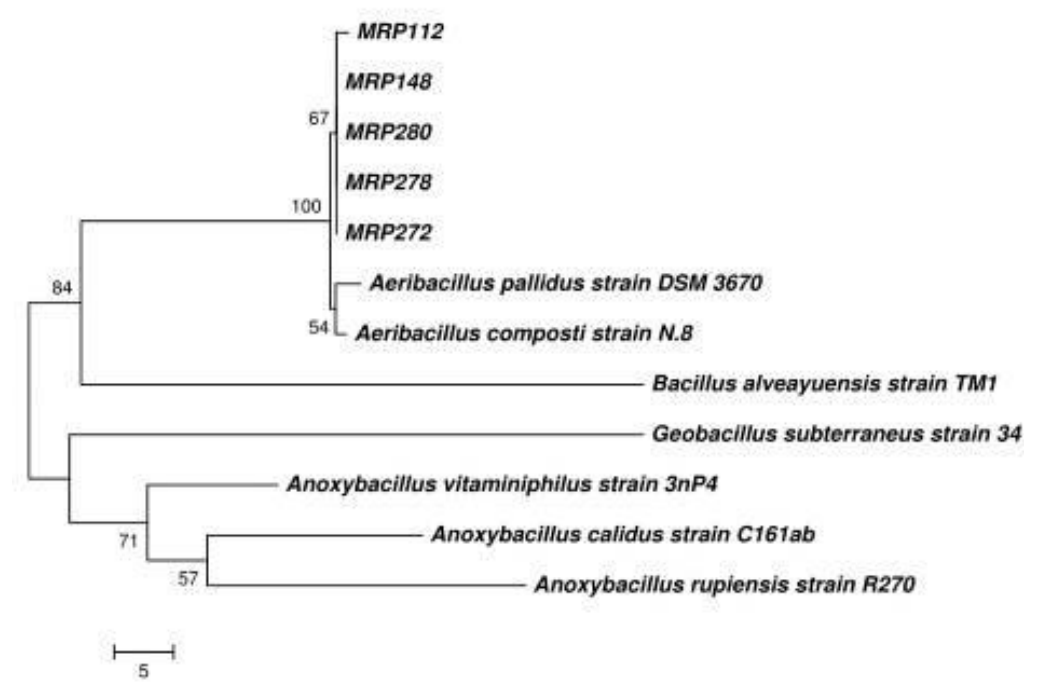

\section{Minimum Inhibitory Concentration (MIC)}

The minimum inhibitory concentrations represent the lowest $\mathrm{Pb}$ concentration that completely inhibited bacterial growth. The MIC both in solid and liquid medium has been shown the same results. Figure 2 represents the MIC data of A. pallidus MRP112, MRP148, MRP272, MRP278, and MRP280 in LB broth. As shown in Figure 2, MIC test indicated that the increase of $\mathrm{Pb}$ in the liquid media from 25-50 mg/L, slightly reduced bacterial growth, compared to the control without $\mathrm{Pb}(0 \mathrm{ppm})$. It was observed that all isolates did not show any growth when exposed to 125 $\mathrm{mg} / \mathrm{L} \mathrm{Pb}$.

Table 1. The comparison of the $16 \mathrm{~S}$ rRNA gene sequences of the selected lead-tolerant bacterial isolates

\begin{tabular}{lc}
\hline Strain ID & GenBank acc. number \\
\hline MRP112 & MT422124 \\
MRP148 & MT422122 \\
MRP272 & MT422121 \\
MRP278 & MT422120 \\
MRP280 & MT422117 \\
\hline
\end{tabular}

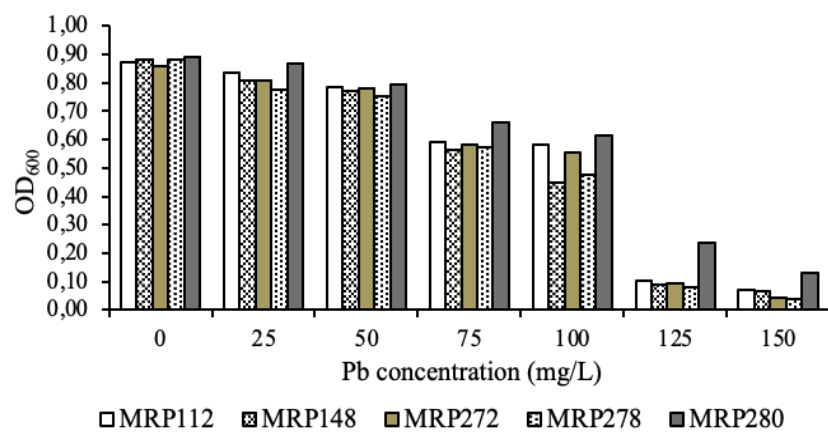

Figure 2. Minimum Inhibitory Concentration (MIC) of Aeribacillus pallidus MRP112, MRP148, MRP272, MRP278 and MRP280

Figure 1. Phylogenetic tree of Aeribacillus pallidus isolates based on 16S rRNA gene sequences 


\section{Pb removal assay}

Percentage of $\mathrm{Pb}$ removal rate by all selected isolates is summarized in Table 2. Among five selected isolates, $A$. pallidus MRP280 showed the highest $\mathrm{Pb}$ removal capability. The $\mathrm{Pb}$ removal capacity of all the selected isolates was highly dependent on the $\mathrm{pH}$ culture medium $(\mathrm{p}<0.05)$.

\section{Biofilm formation}

Biofilm formation assigns the capability of binding significant quantities of metals under natural conditions, and serves as matrices for insoluble mineral phase precipitation (Fomina and Gadd 2014). Table 3 showed that the addition of $\mathrm{Pb}$ had a significantly positive response on the production of biofilms $(\mathrm{p}<0.05)$. It was also found that the increase of $\mathrm{Pb}$ concentrations in medium, resulted in biofilm by all selected isolates.

\section{Siderophores production}

Determination of siderophores production depends on the binding of $\mathrm{Pb}$ ion outside bacterial cell. Enhancing siderophores production is one of bacterial detoxification $\mathrm{Pb}$ mechanism (Naik and Dubey 2013). Moreover, siderophore secreted by bacterial cells had beneficial impacts on the $\mathrm{Pb}$ removal (Ren et al. 2015). It was found that $\mathrm{Pb}$ influenced the increase in siderophore production compared to the control $(\mathrm{p}<0.05)$ (Table 4). This table shows that all tested isolates gave positive response to siderophore assembly. It was also observed that the increase in $\mathrm{Pb}$ concentration correlated with the ability to produce siderophore by all the selected isolates.

\section{Growth profile of Aeribacillus pallidus MRP280}

The impact of $\mathrm{Pb}$ stress and $\mathrm{pH}$ on growth potential of bacteria was observed by bacterial growth curve assessment (Figures 3-5). A. pallidus MRP280 exhibited different growth patterns in the presence of $\mathrm{Pb}$ over an experimental time period of 3 to $24 \mathrm{~h}$ until the growth of bacteria reached stationary phase. The major effect of $\mathrm{Pb}$ stress (50 and $100 \mathrm{mg} / \mathrm{L})$ on this bacterium was manifested in longer stationary phase $(6 \mathrm{~h})$ than the control $(3 \mathrm{~h})$. An increase in lag phase due to the toxic levels of $\mathrm{Pb}$ caused the strain requires some time to acclimatize to the environment (Singh et al. 2019). However, the growth curve pattern suggested that these bacteria exhibited tolerance towards $\mathrm{Pb}$ stress. A lower value of optical density indicated that biomass growth of these bacterial isolates was highly affected by the presence of $\mathrm{Pb}$ in the growth medium.

Table 2. $\mathrm{Pb}$ removal rate (\%) by selected bacterial isolates, Aeribacillus pallidus at $100 \mathrm{mg} / \mathrm{L} \mathrm{Pb}, 55{ }^{\circ} \mathrm{C}$ for $24 \mathrm{~h}$

\begin{tabular}{llllll}
\hline pH & MRP112 & MRP148 & MRP272 & MRP278 & MRP280 \\
\hline 5 & $85.45 \pm 0.48^{\mathrm{c}}$ & $78.35 \pm 0.27^{\mathrm{b}}$ & $75.87 \pm 0.43^{\mathrm{c}}$ & $78.71 \pm 1.02^{\mathrm{b}}$ & $91.85 \pm 0.39^{\mathrm{b}}$ \\
6 & $91.03 \pm 0.87^{\mathrm{a}}$ & $80.48 \pm 0.20^{\mathrm{a}}$ & $87.23 \pm 0.69^{\mathrm{a}}$ & $85.10 \pm 0.15^{\mathrm{a}}$ & $93.53 \pm 0.22^{\mathrm{a}}$ \\
7 & $87.59 \pm 0.78^{\mathrm{b}}$ & $79.06 \pm 0.62^{\mathrm{b}}$ & $82.52 \pm 0.17^{\mathrm{b}}$ & $80.48 \pm 1.20^{\mathrm{b}}$ & $92.43 \pm 0.47^{\mathrm{b}}$ \\
\hline
\end{tabular}

Note: * Means sharing the same superscripted letters at each bacterial isolates are statistically non-significant at $\mathrm{p}<0.05$.

Table 3. Biofilm formation ( $\mathrm{OD}_{595}$ ) by selected bacterial isolates, Aeribacillus pallidus at $55{ }^{\circ} \mathrm{C}$ for $72 \mathrm{~h}$

\begin{tabular}{llllll}
\hline Pb conc. $(\mathbf{m g} / \mathbf{L})$ & MRP112 & MRP148 & MRP272 & MRP278 & MRP280 \\
\hline 0 & $0.067 \pm 0.005^{\mathrm{c}}$ & $0.066 \pm 0.006^{\mathrm{d}}$ & $0.061 \pm 0.003^{\mathrm{d}}$ & $0.067 \pm 0.002^{\mathrm{d}}$ & $0.078 \pm 0.006^{\mathrm{e}}$ \\
25 & $0.074 \pm 0.004^{\mathrm{c}}$ & $0.085 \pm 0.009^{\mathrm{c}}$ & $0.074 \pm 0.004^{\mathrm{c}}$ & $0.071 \pm 0.005^{\mathrm{c}, \mathrm{d}}$ & $0.090 \pm 0.001^{\mathrm{d}}$ \\
50 & $0.087 \pm 0.010^{\mathrm{b}}$ & $0.079 \pm 0.004^{\mathrm{b}, \mathrm{c}}$ & $0.077 \pm 0.004^{\mathrm{c}}$ & $0.080 \pm 0.001^{\mathrm{b}, \mathrm{c}}$ & $0.104 \pm 0.005^{\mathrm{c}}$ \\
75 & $0.103 \pm 0.006^{\mathrm{a}}$ & $0.111 \pm 0.008^{\mathrm{a}}$ & $0.088 \pm 0.009^{\mathrm{b}}$ & $0.076 \pm 0.001^{\mathrm{b}}$ & $0.117 \pm 0.004^{\mathrm{b}}$ \\
100 & $0.100 \pm 0.001^{\mathrm{a}}$ & $0.098 \pm 0.006^{\mathrm{b}}$ & $0.113 \pm 0.005^{\mathrm{a}}$ & $0.110 \pm 0.002^{\mathrm{a}}$ & $0.134 \pm 0.006^{\mathrm{a}}$ \\
\hline
\end{tabular}

Note: * Means sharing the same letters at each bacterial isolates are statistically non-significant at $\mathrm{p}<0.05$.

Table 4. Units siderophore production (\%) by selected bacterial isolates, Aeribacillus pallidus at $55{ }^{\circ} \mathrm{C}$ for $24 \mathrm{~h}$

\begin{tabular}{llllll}
\hline Pb conc. $(\mathbf{m g} / \mathbf{L})$ & MRP112 & MRP148 & MRP272 & MRP278 & MRP280 \\
\hline 0 & $4.10 \pm 0.56^{\mathrm{d}}$ & $7.70 \pm 0.10^{\mathrm{d}}$ & $6.67 \pm 0.65^{\mathrm{c}}$ & $3.97 \pm 0.21^{\mathrm{e}}$ & $7.60 \pm 0.10^{\mathrm{e}}$ \\
25 & $7.30 \pm 0.53^{\mathrm{c}}$ & $13.27 \pm 1.96^{\mathrm{c}}$ & $10.50 \pm 0.44^{\mathrm{c}}$ & $7.37 \pm 0.55^{\mathrm{d}}$ & $12.40 \pm 1.17^{\mathrm{d}}$ \\
50 & $19.80 \pm 1.21^{\mathrm{b}}$ & $25.13 \pm 0.32^{\mathrm{b}}$ & $23.60 \pm 6.06^{\mathrm{b}}$ & $20.40 \pm 0.10^{\mathrm{c}}$ & $31.20 \pm 0.40^{\mathrm{c}}$ \\
75 & $20.67 \pm 0.15^{\mathrm{b}}$ & $28.33 \pm 0.57^{\mathrm{a}}$ & $27.60 \pm 0.20^{\mathrm{b}}$ & $22.53 \pm 0.38^{\mathrm{b}}$ & $31.77 \pm 0.38^{\mathrm{b}}$ \\
100 & $27.33 \pm 1.24^{\mathrm{a}}$ & $28.97 \pm 0.06^{\mathrm{a}}$ & $29.43 \pm 0.45^{\mathrm{a}}$ & $25.97 \pm 0.35^{\mathrm{a}}$ & $38.63 \pm 2.28^{\mathrm{a}}$ \\
\hline
\end{tabular}

Note: * Means sharing the same letters at each bacterial isolates are statistically non-significant at $\mathrm{p}<0.05$ 


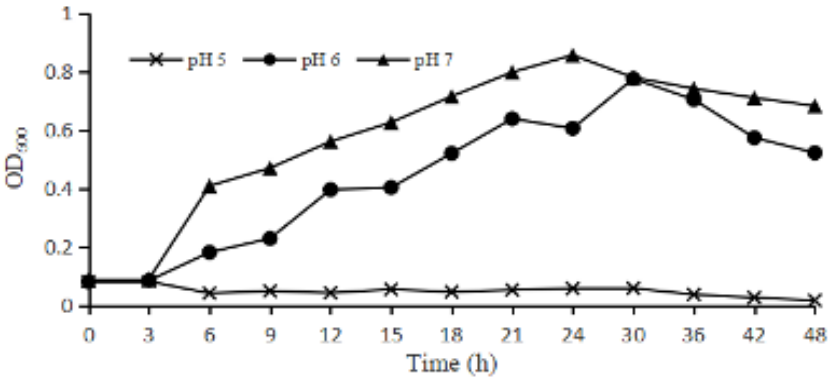

Figure 3. Aeribacillus pallidus MRP280 growth profile without $\mathrm{Pb}$ at $55^{\circ} \mathrm{C}$

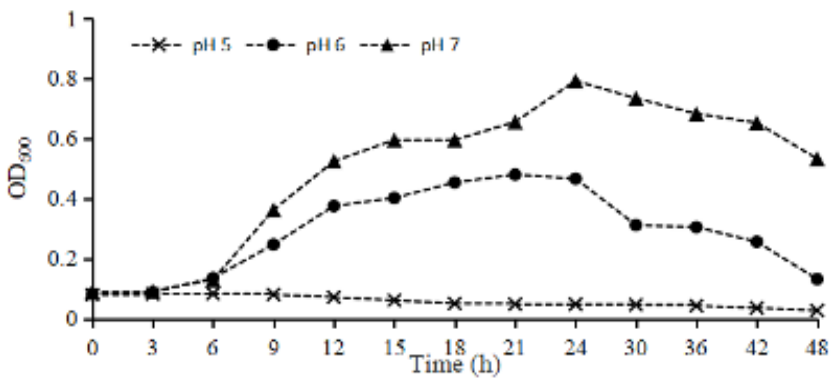

Figure 4. Aeribacillus pallidus MRP280 growth profile with addition $50 \mathrm{ppm} \mathrm{Pb}$ at $55^{\circ} \mathrm{C}$

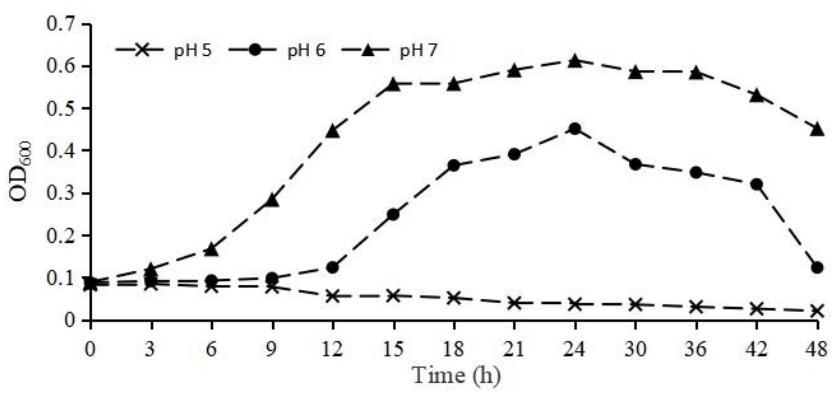

Figure 5. Aeribacillus pallidus MRP280 growth profile with addition $100 \mathrm{ppm} \mathrm{Pb}$ at $55^{\circ} \mathrm{C}$

The effect of $\mathrm{pH}$ on A. pallidus MRP280 growth is shown in Figures 3-5. It was observed that the isolate demonstrated growth at $\mathrm{pH} 6$ and $\mathrm{pH} 7$, while at $\mathrm{pH} 5$, no growth was observed. A higher optical density value at $\mathrm{pH}$ 7 than $\mathrm{pH} 6$ indicated that $\mathrm{pH} 7$ was found optimum for $A$. pallidus MRP280. The results of this study confirm previous report that the optimum growth of A. pallidus was obtained at pH 7-8 (Yasawong et al. 2011). The growth patterns of the bacteria at $\mathrm{pH} 6$ and 7 with concentrations $\mathrm{Pb} 0$ and $50 \mathrm{mg} / \mathrm{L}$ were relatively similar. However, at concentration $\mathrm{Pb} 100 \mathrm{mg} / \mathrm{L}$ the growth curves were slightly different. The lag phase for bacterial growth at $\mathrm{pH} 6$ was found extended up 9 has compared to growth at $\mathrm{pH} 7$ which lasted for $6 \mathrm{~h}$.

The amounts of $\mathrm{Pb}$ desorbed by milli-Q water, $\mathrm{NH}_{4} \mathrm{NO}_{3}$, and EDTA-Na 2 were $4.7 \%, 11.19 \%$, and $41.82 \%$ respectively. Several mechanisms responsible for the binding of $\mathrm{Pb}$ ions to bacterial cells can be quantitatively assessed using appropriate desorption reagents. When $\mathrm{Pb}$ ions come into contact with bacterial cells, some ions enter into the cell wall mesh structure and are adsorbed by physical entrapment. This fraction is bound weakly and can be desorbed by water. A second fraction that is exchangeable with $\mathrm{K}^{+}, \mathrm{Ca}^{2+}, \mathrm{Na}^{+}$, and $\mathrm{Mg}^{2+}$ on cell wall polysaccharides can be desorbed by $\mathrm{NH}_{4} \mathrm{NO}_{3}$. A third fraction that complexes with cell wall functional groups such as carboxyl and phosphate groups can be desorbed by EDTA but not by water or $\mathrm{NH}_{4} \mathrm{NO}_{3}$ (Y. Li, Yue, and Gao 2010; Fang et al. 2011). These results revealed that the $\mathrm{Pb}$ ions adsorbed by $A$. pallidus MRP280 cell, $4.7 \%$ was physically entrapped, $11.19 \%$ was held by ion exchange, $41.82 \%$ was complexed with functional groups, and $42.3 \%$ was accumulated inside cells (Figure 6).

\section{$\mathrm{Pb}$ precipitates characterization}

FT-IR analysis was carried out to investigate whether the interaction of lead with bacterial cells was due to a biosorption process of lead ions with functional groups of cell surface. Comparison of A. pallidus MRP280 cells spectra loaded with $\mathrm{Pb}$ metal ions is shown in Figure 7. The zone range of $2900-3400 \mathrm{~cm}^{-1}, 1350-1450 \mathrm{~cm}^{-1}$, and $700-$ $800 \mathrm{~cm}^{-1}$ showed remarkable changes in the shape and intensity of peaks, indicating bacterial cell exhibited considerable changes in $\mathrm{N}-\mathrm{H}, \mathrm{C}-\mathrm{H}, \mathrm{C}=\mathrm{O}$, and $\mathrm{C}-\mathrm{C}$ groups and thus supporting the adsorption of $\mathrm{Pb}$. Lead ions interact with functional groups of proteins and phosphate groups on the cell surface.

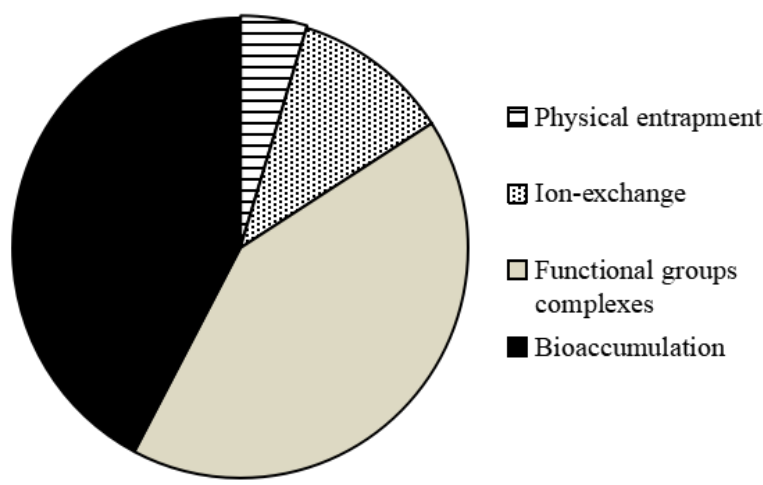

Figure 6. $\mathrm{Pb}$ distribution in Aeribacillus pallidus MRP280 cell at pH 6 after 24 hours

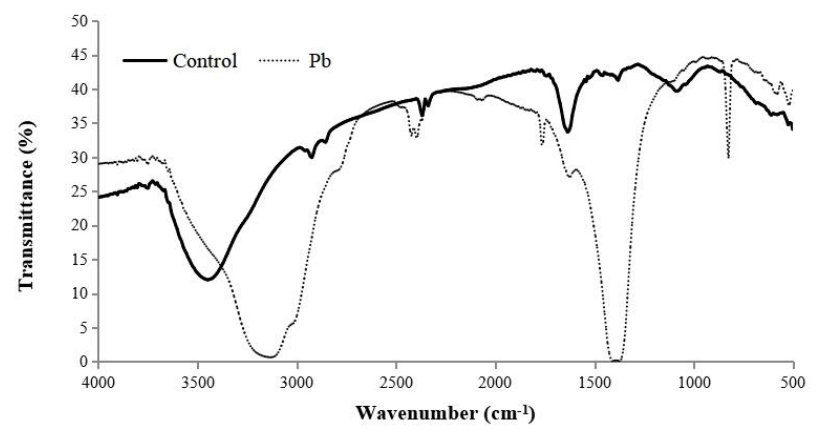

Figure 7. FTIR analysis of Aeribacillus pallidus MRP280 cell with $(\mathrm{Pb})$ and without $\mathrm{Pb}$ (control) 


\section{Bioaccumulation and biosorption assay}

The morphological differences of A. pallidus MRP280 in the presence of $\mathrm{Pb}$ were examined by SEM-EDX (Figure 8). It is clearly demonstrated that bacteria grew in an aggregated formation and as intact morphological features in the medium without heavy metals (Figure 8.A). Under heavy metals, however, cells showed an aggregated form, disrupted cell wall, and highly distorted morphological features (Figure 8.B). To investigate further the intracellular accumulation and extracellular absorption of heavy metals, a TEM analysis was conducted. Figure 9 showed an obviously closed region with a double-layer border in each TEM picture representing cell wall in the cross-section of cell. The dark spots in the external region indicated that $\mathrm{Pb}$ was distributed uniformly in the periplasmic space and cell surface, while the dark spots in the internal region showed $\mathrm{Pb}$ precipitation, suggesting the possibility of $\mathrm{Pb}$ bioaccumulation inside the cell.

\section{Discussion}

Five isolates isolated from Mount Merapi, Indonesia, designated as isolates MRP112, MRP148, MRP272, MRP278, and MRP280 showed tolerance to $\mathrm{Pb}$ at very high concentrations $(100 \mathrm{mg} / \mathrm{L})$. BLAST analysis of all isolates revealed highest sequence similarity (100\%) with Aeribacillus pallidus. Despite the fact that A. pallidus have been obtained from various high-temperature environment, no lead tolerant strain has been recorded so far (Adigüzel et al. 2011; Yasawong et al. 2011; Mnif et al. 2014; Muhammad and Ahmed 2015; Aanniz et al. 2015, Filippidou et al. 2015; Bose and Satyanarayana 2016; Poltaraus et al. 2016; Mechri et al. 2017; Baltaci et al. 2017; Arab et al. 2019; Ma et al. 2019; Mehetre et al. 2019; Ktata et al. 2020).

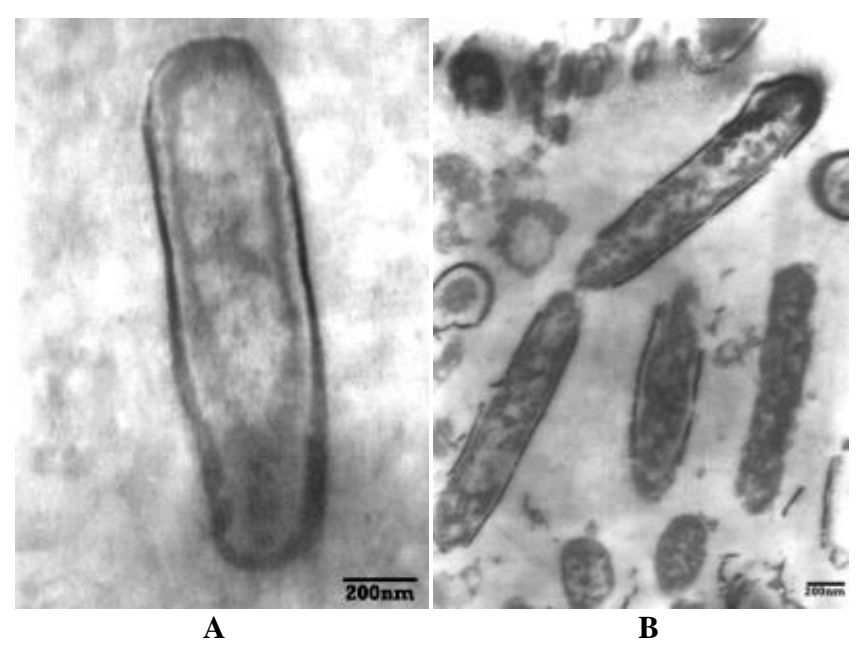

Figure 9. TEM analysis of Aeribacillus pallidus MRP280 (A) without $\mathrm{Pb}$ (B) $100 \mathrm{mg} / \mathrm{L} \mathrm{Pb}$

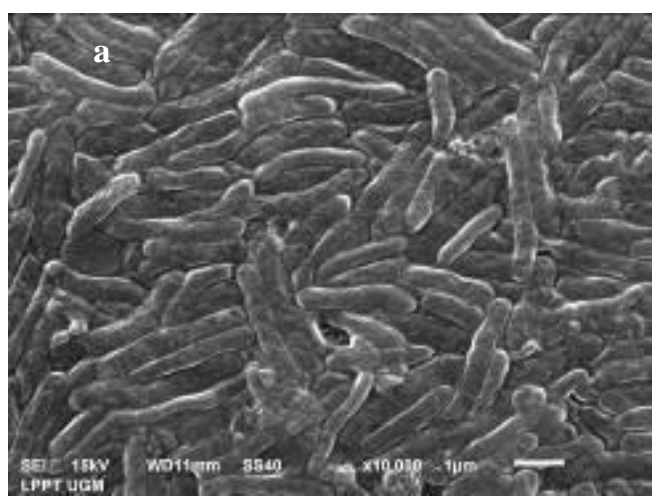

A

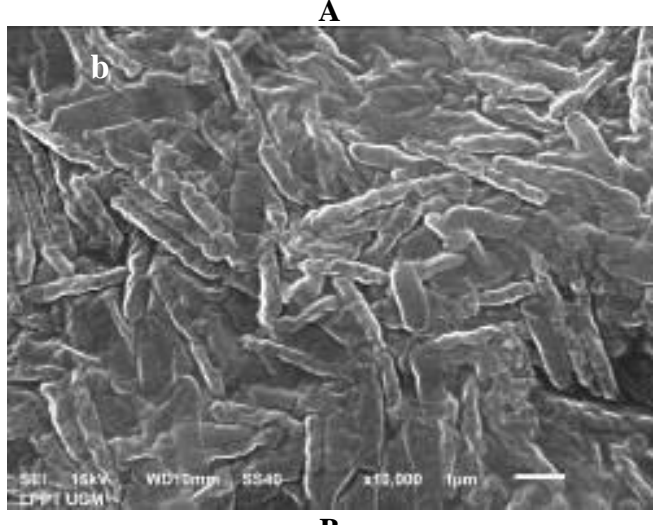

B
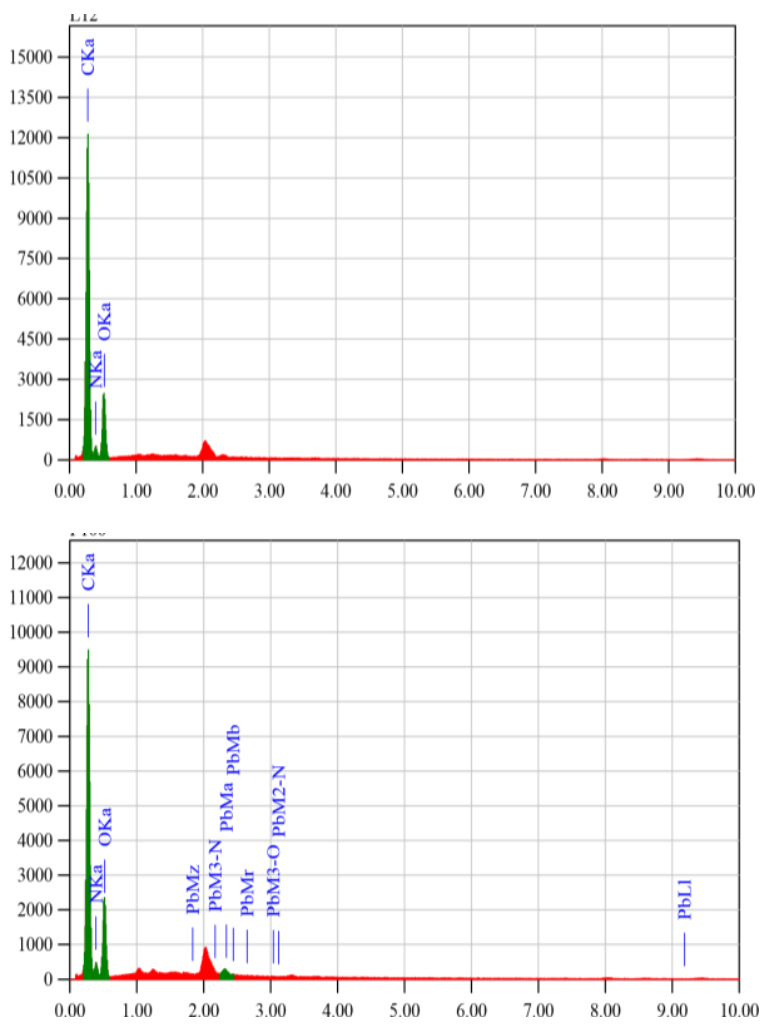

Figure 8. SEM-EDX analysis of Aeribacillus pallidus MRP280 (A) without $\mathrm{Pb}$ (B) $100 \mathrm{mg} / \mathrm{L} \mathrm{Pb}$ 
The order of cell growth for all five isolates was found to be A. Pallidus MRP280>MRP112>MRP272>MRP278> MRP148 at $100 \mathrm{mg} / \mathrm{L}$ of $\mathrm{Pb}$ solution, suggesting strong $\mathrm{Pb}$ tolerance potential of $A$. pallidus MRP280. The major factor determining the toxicity of $\mathrm{Pb}$ to bacteria is probably the extent to which they penetrate cytoplasm (Aljerf and AlMasri 2018), that damages the bacterial cell membranes, and destroys DNA structure (Igiri et al. 2018). This study demonstrated different findings in comparison with previous study. A marked negative effect of $\mathrm{Pb}$ on thermophilic bacteria, Thermus thermophilus growth was only observed at 200 and $300 \mathrm{mg} / \mathrm{L}$ (Nicolaus et al. 2016) which might be attributed to the differences in the strains, observed growth stage, growth media composition, and temperature.

The removal of $\mathrm{Pb}$ in the bacterial cell was greatly enhanced and reached the maximum value at $\mathrm{pH} 6$, related to the availability of free binding sites depending on the $\mathrm{pH}$. The anionic functional groups present in the cell envelop were the components primarily responsible for the metal-binding capability of the bacterium (Chakravarty and Banerjee 2012). At lower $\mathrm{pH}(\mathrm{pH} 5)$, more $\mathrm{H}^{+}$was present that can protonate the functional groups in the bacterial cell reducing the negative surface, meanwhile, most of $\mathrm{Pb}(\mathrm{II})$ is present as $\mathrm{Pb}^{2+}$. This condition inhibited the interaction of $\mathrm{Pb}$ on the bacterial cell. In addition, bacteria cannot grow at pH 5 as seen in Figures 3-5 which suggested that sufficient number of cells was not achieved at $\mathrm{pH} 5$, compared to $\mathrm{pH}$ 6 and 7. The increase of $\mathrm{pH}(\mathrm{pH} 6)$ resulted in the reduction of the $\mathrm{H}^{+}$number, which further decreased the protonation which gave negative surface of the cell favorable for the biosorption of $\mathrm{Pb}$ ions by A. pallidus MRP280. Higher $\mathrm{pH}$ $(\mathrm{pH}$ 7) also significantly reduced the solubility of $\mathrm{Pb}$, forming $\mathrm{Pb}$ hydroxides, which collides and thus impedes the biosorption. These $\mathrm{pH}$ values are different from those previously reported that $\mathrm{Pb}$ maximum adsorption by thermophilic bacteria non-living biomass Geobacillus thermodenitrificans was observed at $\mathrm{pH} 4.5$ (Chatterjee et al. 2010). In this study, $\mathrm{Pb}$ adsorption was determined by living and non-living bacterial cells in LB medium, thus, an overestimation of $\mathrm{pH}$ values must be considered.

Among all isolates, it was found that A. pallidus MRP280 formed the thickest biofilm at $100 \mathrm{mg} / \mathrm{L}$ of $\mathrm{Pb}$ after $24 \mathrm{~h}$. It indicated that this isolate was the most $\mathrm{Pb}$ tolerant among all isolates. Villegas et al. (2018) reported that bacterial cell which formed the thickest biofilm was believed as the heaviest metals tolerant bacteria. Several studies showed that $\mathrm{Pb}$-tolerant bacteria could produce biofilm as reported by numerous studies on Klebsiella sp. 3S1 (Muñoz et al. 2012); Bacillus pumilus (Pepi et al. 2016); Aeribacillus pallidus E334 (Kilic et al. 2017); Pseudomonas pseudoalcaligenes NP103 (Kumari et al. 2017); Rhodococcus equi, R. opacus, Pseudomonas aeruginosa, Bacillus megaterium, Solibacillus silvestris, Enterococcus faecium, and Bacillus sp. (Villegas et al. 2018).

Aeribacillus pallidus MRP280 was identified as the highest siderophore producer at $100 \mathrm{mg} / \mathrm{L}$ of $\mathrm{Pb}$. It is, therefore, proposed that this isolate may be elaborated further as a candidate for $\mathrm{Pb}$ bioremediator agent. Tiquia
(2018) stated that the siderophore's ability to reduce the mobility of $\mathrm{Pb}$ in the environment by forming stable metalligand complexes makes them an ideal strategy for $\mathrm{Pb}$ remediation. Similarly, siderophore-producing bacteria in the presence $\mathrm{Pb}$ ion have been studied on Kluyvera ascorbata SUD165 (Burd et al. 2000); Pseudomonas putida KNP9 (Tripathi et al. 2005); Pseudomonas aeruginosa 4EA (Naik and Dubey 2011); Bacillus amyloliquefaciens NAR38.1 (Gaonkar and Bhosle 2013); Bacillus sp. PZ-1 (Yu et al. 2017); Pseudomonas sp. B50D (Giovanella et al. 2017).

Bioaccumulation and biosorption assay revealed that the $\mathrm{Pb}$ ions adsorbed by A. pallidus MRP280 cell, was $4.7 \%$ physically entrapped, $11.19 \%$ was held by ion exchange, $41.82 \%$ was complexed with functional groups, and $42.3 \%$ was accumulated inside cells. According to Bai et al. (2014), the dominant binding mechanisms of the total amount of $\mathrm{Pb}$ (II) adsorbed by Bacillus subtilus DBM, were ion-exchange and intracellular accumulation (43.4\% and $38.5 \%$, respectively) for living cells. For non-living cells, on the other hand, ion exchange and complexation with functional groups were the dominant mechanisms $(34.9 \%$ and $34.3 \%$, respectively). The results from these studies, however, may not be directly comparable to the present study as there were experimental conditions differences i.e., bacterial strain, $\mathrm{pH}$, temperature, initial $\mathrm{Pb}$ concentration, contact time, biomass weight, and cell condition (living or non-living cells).

As a result of the addition of $\mathrm{Pb}$, A. pallidus MRP280 cells became twisted with stretched cell size and surrounded by numerous cell debris in comparison to the control. The feature of $\mathrm{Pb}$ bioprecipitation showed distinct morphological alterations, deformation, and severe membrane damage, indicating $\mathrm{Pb}$ toxicity to bacteria. Additionally, cell debris could be a matrix of exopolysaccharides which was secreted to protect the cell from metals or to retain metals by adsorption and prevent accumulation into the cells (Shao et al. 2019).

Thermophilic bacteria isolated from solfatara Mount Merapi demonstrated their ability to tolerate relatively higher concentrations of $\mathrm{Pb} 100 \mathrm{mg} / \mathrm{L}$ and thus suggesting their potential for $\mathrm{Pb}$ removal. One of the isolates, $A$. pallidus MRP280 demonstrated the highest MIC and $\mathrm{Pb}$ removal capacity. Moreover, it was also clearly demonstrated that lead tolerance was facilitated by morphological changes, bioaccumulation, biosorption, biofilm, and siderophore assembly. Further investigations are necessary to explore the capability of this thermophilic bacteria to remove $\mathrm{Pb}$ from contaminated environments.

\section{ACKNOWLEDGEMENTS}

The authors would like to appreciate all colleagues and technicians for their assistance during the course of the research, especially Evy Yulianti. This study was financially supported by The Indonesian Endowment Fund for Education (LPDP), Ministry of Finance, Republic of Indonesia. The authors greatly aknowledged the support of Universitas Gadjah Mada, Yogyakarta, and Universitas 
Negeri Yogyakarta for the completion of this study. The authors declare no conflict of interest.

\section{REFERENCES}

Aanniz T, Ouadghiri M, Melloul M, Swings J, Elfahime E, Ibijbijen J, Ismaili M, Amar M. 2015. Thermophilic bacteria in Moroccan hot springs, salt marshes, and desert soils. Brazil J Microbiol 46 (2): $443-$ 453. DOI: $10.1590 / \mathrm{S} 1517-838246220140219$.

Abbas SH, Ali WH. 2018. Electrocoagulation technique used to treat wastewater: a review. Am J Eng Res 10: 74-88.

Abdi O, Kazemi M. 2015. A review study of biosorption of heavy metals and comparison between different biosorbents. J Mater Environ Sci 6 (5): 1386-1399.

Adigüzel A, Inan K, Şahin F, Arasoğlu T, Güllüce M, Beldüz AO, Bariş Ö. 2011. Molecular diversity of thermophilic bacteria isolated from Pasinler Hot Spring (Erzurum, Turkey). Turk J Biol 35 (3): 267-274. DOI: 10.3906/biy-0908-7.

Akinterinwa A, Adibayo I. 2018. Chemical precipitation approach to the removal of heavy metals from wastewater for discharge into sanitary sewerage bioremediation of water view project environment view project. Intl J Chem 1(2): 167-171

Aljerf L, AlMasri N. 2018. A gateway to metal resistance: bacteria response to heavy metal toxicity in the biological environment. Ann Adv Chem: 032-044. DOI: 10.29328/journal.aac.1001012.

Al-Khafaji KAA, Mouhamad RS, Mahmood SAA, Mohamed AA, Mahd HH. 2018. Bioremediation of lead by Iraqi isolate of thermophilic bacteria Bacillus stearothermophilus. Adv Agric Technol Plant Sci 1 (4): 1-5.

Arab M, Bakour S, Lalaoui R, Aissaoui N, Nas F, Hoceini A, Fournier PE, Klouche-Khelil N. 2019. Diversity of aerobic bacilli analysis using molecular and culture-based approaches in Debagh Hot Spring. Geomicrobiol J $36 \quad$ (2): 137-47. DOI: 10.1080/01490451.2018.1520937.

Arora NK, Verma M. 2017. Modified microplate method for rapid and efficient estimation of siderophore produced by bacteria. 3 Biotech, 7: 381 DOI: $10.1007 / \mathrm{s} 13205-017-1008-y$

Ayangbenro AS, Babalola OO. 2017. A new strategy for heavy metal polluted environments: a review of microbial biosorbents. Intl J Environ Res Public Health 14 (1). DOI: 10.3390/ijerph14010094.

Babák L, Šupinová P, Zichová M, Burdychová R, Vítová E. 2012. Biosorption of $\mathrm{Cu}, \mathrm{Zn}$ and $\mathrm{Pb}$ by thermophilic bacteria - effect of biomass concentration on biosorption capacity. Acta Univ Agric et Silviculturae Mendelianae Brunensis 60 (5): 9-18. DOI 10.11118/actaun201260050009.

Bai J, Yang X, Du R, Chen Y, Wang S, Qiu R. 2014. Biosorption mechanisms involved in immobilization of soil $\mathrm{Pb}$ by Bacillus Subtilis DBM in a multi-metal-contaminated soil. J Environ Sci (China) 26 (10): 2056-2064. DOI: 10.1016/j.jes.2014.07.015.

Baltaci MO, Genc B, Arslan S, Adiguzel G, Adiguzel A. 2017. Isolation and characterization of thermophilic bacteria from geothermal areas in turkey and preliminary research on biotechnologically important enzyme production. Geomicrobiol J 34 (1): 53-62. DOI 10.1080/01490451.2015.1137662.

Bezzina JP, Ruder LR, Dawson R, Ogden MD. 2019. Ion exchange removal of $\mathrm{Cu}$ (II), $\mathrm{Fe}(\mathrm{II}), \mathrm{Pb}(\mathrm{II})$, and $\mathrm{Zn}$ (II)from acid extracted sewage sludge - resin screening in weak acid media. Water Res 158 : 257-267. DOI: 10.1016/j.watres.2019.04.042.

Bose H, Satyanarayana T. 2016. Suitability of the alkalistable carbonic anhydrase from a polyextremophilic bacterium Aeribacillus pallidus TSHB1 in biomimetic carbon sequestration. Bioprocess Biosyst Eng 39 (10): 1515-1525. DOI: 10.1007/s00449-016-1627-4

Building T. 2010. Electron Microscopy Procedures Manual. Fred Hutchinson Cancer Research Center, Seattle, WA.

Burd GI, Dixon DG, Glick BR. 2000. Plant growth-promoting bacteria that decrease heavy metal toxicity in plants. Can J Microbiol 46 (3): 237-245. DOI: 10.1139/w99-143.

Chakravarty R, Banerjee PC. 2012. Mechanism of cadmium binding on the cell wall of an acidophilic bacterium. Bioresour Technol 108: 176-183. DOI: 10.1016/j.biortech.2011.12.100

Chatterjee SK, Bhattacharjee I, Chandra G. 2010. Biosorption of heavy metals from industrial waste water by Geobacillus thermodenitrificans. J Hazard Mater 175 (1-3): 117-125. DOI: 10.1016/j.jhazmat.2009.09.136.

Chaudhary A, Shirodkar S, Sharma A. 2017. Characterization of nicke tolerant bacteria isolated from heavy metal polluted glass industry for its potential role in bioremediation. Soil Sediment Contam 26 (2): 184-194. DOI: 10.1080/15320383.2017.1267110.

Fang L, Zhou C, Cai P, Chen W, Rong X, Dai K, Liang W, Gu GD, Huang Q. 2011. Binding characteristics of copper and cadmium by cyanobacterium Spirulina platensis. J Hazard Mater 190 (1-3): 810815. DOI: 10.1016/j.jhazmat.2011.03.122.

Filippidou S, Jaussi M, Junier T, Wunderlin T, Jeanneret N, Regenspurg S, Li PO et al. 2015. Genome Sequence of Aeribacillus pallidus Strain GS3372, an Endospore-Forming Bacterium Isolated in a Deep Geothermal Reservoir. Genome Announc 3 (4): 5-6. DOI: 10.1128/genomeA.00981-15.

Fomina M, Gadd GM. 2014. Biosorption: current perspectives on concept, definition and application. Bioresour Technol 160: 3-14. DOI: 10.1016/j.biortech.2013.12.102.

Gaonkar T, Bhosle S. 2013. Effect of metals on a siderophore producing bacterial isolate and its implications on microbial assisted bioremediation of metal contaminated soils. Chemosphere 93 (9): 1835-1843. DOI: 10.1016/j.chemosphere.2013.06.036

Ghasemi M, Naushad M, Ghasemi N, Khosravi-fard Y. 2014. Adsorption of $\mathrm{Pb}$ (II) from aqueous solution using new adsorbents prepared from agricultural waste: adsorption isotherm and kinetic studies. J Ind Eng Chem 20 (4): 2193-2199. DOI: 10.1016/j.jiec.2013.09.050.

Giovanella P, Cabral L, Costa AP, Camargo FA, Gianello C, Bento FM. 2017. Metal resistance mechanisms in gram-negative bacteria and their potential to remove $\mathrm{hg}$ in the presence of other metals. Ecotoxicol Environ Saf 140: 162-169. DOI: 10.1016/j.ecoenv.2017.02.010.

Gupta A, Joia J. 2016. Microbes as potential tool for remediation of heavy metals: a review. J Microb Biochem Technol 8 (4): 364-372. DOI: 10.4172/1948-5948.1000310.

Igiri BE, Okoduwa SIR, Idoko GO, Akabuogu EP, Adeyi AO, Ejiogu IK. 2018. Toxicity and bioremediation of heavy metals contaminated ecosystem from tannery wastewater: a review. J Toxicol. Article ID 2568038. DOI: $10.1155 / 2018 / 2568038$.

Jacob JM, Karthik C, Saratale RG, Kumar SS, Prabakar D, Kadirvelu K, Pugazhendhi A. 2018. Biological approaches to tackle heavy metal pollution: a survey of literature. J Environ Manag 217: 56-70. DOI: 10.1016/j.jenvman.2018.03.077.

Jiang Y, Hao R, Yang S. 2016. Equilibrium and kinetic studies on biosorption of $\mathrm{Pb}$ (II) by common edible macrofungi: a comparative study. Can J Microbiol 62 (4): 329-337. DOI: 10.1139/cjm-20150631

Kalita D, Joshi SR. 2017. Study on bioremediation of lead by exopolysaccharide producing metallophilic bacterium isolated from extreme habitat. Biotechnol Rep 16: 48-57. DOI: 10.1016/j.btre.2017.11.003

Kilic T, Karaca B, Ozel BP, Ozcan B, Cokmus C, Cihan AC. 2017. Biofilm Characteristics and Evaluation of the Sanitation Procedures of Thermophilic Aeribacillus pallidus E334 Biofilms. Biofouling 33 (4): 352-367. DOI: 10.1080/08927014.2017.1313412.

Ktata A, Krayem N, Aloulou A, Bezzine S, Sayari A, Chamkha M, Karray A. 2020. Purification, biochemical and molecular study of lipase producing from a newly thermoalkaliphilic Aeribacillus pallidus for oily wastewater treatment. J Biochem 167(1): 89-99. DOI: $10.1093 / \mathrm{jb} / \mathrm{mvz} 083 / 5585010$

Kumar S, Stecher G, Li M, Knyaz C, Tamura K. 2018. MEGA X: Molecular Evolutionary Genetics Analysis across computing platforms. Mol Biol Evol 35 (6): 1547-1549. DOI: 10.1093/molbev/msy096.

Kumari S, Mangwani N, Das S. 2017. Interaction of $\mathrm{Pb}$ (II) and biofilmassociated extracellular polymeric substances of a marine bacterium Pseudomonas pseudoalcaligenes NP103. Spectrochimica Acta Part A Mol Biomol Spectrosc 173: 655-665. DOI: 10.1016/j.saa.2016.10.009.

Kushwaha A, Hans N, Kumar S, Rani R. 2018. A critical review on speciation, mobilization and toxicity of lead in soil-microbe-plant system and bioremediation strategies. Ecotoxicol Environ Saf 147: 1035-1045. DOI: 10.1016/j.ecoenv.2017.09.049.

Li C, Xu Y, Jiang W, Dong X, Wang D, Liu B. 2013. Effect of $\mathrm{NaCl}$ on the heavy metal tolerance and bioaccumulation of Zygosaccharomyces rouxii and Saccharomyces cerevisiae Bioresour Technol 143: 46-52. DOI: 10.1016/j.biortech.2013.05.114. 
Li Y, Yue Q, Gao B. 2010. Adsorption kinetics and desorption of $\mathrm{Cu}(\mathrm{II})$ and $\mathrm{Zn}$ (II) from aqueous solution onto humic acid. J Hazard Mater 178 (1-3): 455-461. DOI: 10.1016/j.jhazmat.2010.01.103.

Ma Y, Zhong H, He Z. 2019. Cr(VI) reductase activity locates in the cytoplasm of Aeribacillus pallidus BK1, a novel Cr(VI)-reducing thermophile isolated from Tengchong Geothermal Region, China. Chem Eng J 524-534. DOI: 10.1016/j.cej.2019.04.085.

Mechri S, Berrouina MBE, Benmrad MO, Jaouadi NZ, Rekik H, Moujehed E, Chebbi A, Sayadi S, Chamka M, Bejar S, Jaouadi B. 2017. Characterization of a novel protease from Aeribacillus pallidus strain VP3 with potential biotechnological interest. Intl J Biol Macromol 94: 221-32. DOI: 10.1016/j.ijbiomac.2016.09.112.

Mehetre GT, Dastager SG, Dharne MS. 2019. Biodegradation of mixed polycyclic aromatic hydrocarbons by pure and mixed cultures of biosurfactant producing thermophilic and thermo-tolerant bacteria. Sci Total Environ 679: 52-60. DOI: 10.1016/j.scitotenv.2019.04.376.

Mnif S, Sayadi S, Chamkha M. 2014. Biodegradative potential and characterization of a novel aromatic-degrading bacterium isolated from a geothermal oil field under saline and thermophilic conditions. Intl Biodeterior Biodegradation 86: 258-264. DOI: 10.1016/j.ibiod.2013.09.015.

Muhammad SA, Ahmed S. 2015. Production and characterization of a new antibacterial peptide obtained from Aeribacillus pallidus SAT4. Biotechnol Rep 8: 72-80. DOI: 10.1016/j.btre.2015.09.003.

Muñoz AJ, Ruiz E, Abriouel H, Gálvez A, Ezzouhri L, Lairini K, Espínola F. 2012. Heavy metal tolerance of microorganisms isolated from wastewaters: identification and evaluation of its potential for biosorption. Chem Eng J 210: 325-332. DOI 10.1016/j.cej.2012.09.007.

Naik MM, Dubey SK. 2011. Lead-enhanced siderophore production and alteration in cell morphology in a Pb-resistant Pseudomonas aeruginosa strain 4EA. Curr Microbiol 62 (2): 409-414. DOI: 10.1007/s00284-010-9722-2.

Naik MM, Dubey SK. 2013. Lead resistant bacteria: lead resistance mechanisms, their applications in lead bioremediation and biomonitoring. Ecotoxicol Environ Saf 98: 1-7. DOI: 10.1016/j.ecoenv.2013.09.039.

Neethu CS, Rahiman KMM, Saramma AV, Hatha AAM. 2015. Heavymetal resistance in gram-negative bacteria isolated from Kongsfjord, Arctic. Can J Microbiol 61 (6): 429-435. DOI: 10.1139/cjm-20140803 .

Nicolaus B, Poli A, Donato PD, Romano I, Laezza G, Gioiello A, Ulgiati $\mathrm{S}$, et al. 2016. $\mathrm{Pb}^{2+}$ Effects on growth, lipids, and protein and DNA profiles of the thermophilic bacterium Thermus thermophilus. Microorganisms 4 (4): 45. DOI: 10.3390/microorganisms4040045.

Özdemir S, Kilinç E, Okumuş V, Poli A, Nicolaus B, Romano I. 2016. Thermophilic Geobacillus galactosidasius sp. nov. loaded $\gamma-\mathrm{Fe}_{2} \mathrm{O}_{3}$ magnetic nanoparticle for the preconcentrations of $\mathrm{Pb}$ and $\mathrm{Cd}$. Bioresour Technol 201: 269-275. DOI: 10.1016/j.biortech.2015.11.052.

Peens J, Yu YW, Brink HG. 2018. Microbial Pb (II) precipitation: the influence of elevated $\mathrm{Pb}$ (II) concentrations. Chem Eng Trans 64: 1453-1458.

Penaloza-Vazquez A, Ma LM, Rayas-Duarte P. 2019. Isolation and characterization of Bacillus spp. strains as potential probiotics for poultry. Can J Microbiol 65 (10): 762-774. DOI: 10.1139/cjm-20190019 .

Pepi M, Borra M, Tamburrino S, Saggiomo M, Viola A, Biffali E, Balestra C, Sprovieri M, Casotti R. 2016. A Bacillus sp. isolated from sediments of the Sarno River Mouth, Gulf of Naples (Italy) produces a biofilm biosorbing $\mathrm{Pb}(\mathrm{II})$. Sci Total Environ 562: 588-595. DOI: 10.1016/j.scitotenv.2016.04.097.

Poltaraus AB, Sokolova DS, Grouzdev DS, Ivanov TM, Malakho SG, Korshunova AC, Rozanov AS, Tourova TP, Nazina TN. 2016. Draft genome sequence of Aeribacillus pallidus Strain 8m3, a thermophilic hydrocarbon-oxidizing bacterium isolated from the Dagang Oil Field (China). Genome Announc 4 (3): 4-5. DOI: 10.1128/genomeA.00500-16.

Ren G, Jin Y, Zhang C, Gu H, Qu J. 2015. Characteristics of Bacillus sp. $\mathrm{PZ}-1$ and its biosorption to $\mathrm{Pb}$ (II). Ecotoxicol Environ Saf 117: 141148. DOI: 10.1016/j.ecoenv.2015.03.033.

Schwyn B, Neilands JB. 1987. Universal chemical assay for the detection and determination of siderophores. Anal Biochem 160 (1): 47-56. DOI: 10.1016/0003-2697(87)90612-9.

Sen SK, Raut S, Dora TK, Mohapatra PKD. 2014. Contribution of hot spring bacterial consortium in cadmium and lead bioremediation through quadratic programming model. J Hazard Mater 265: 47-60. DOI: 10.1016/j.jhazmat.2013.11.036.

Shao W, Li M, Teng Z, Qiu B, Huo Y, Zhang K. 2019. Effects of Pb(II) and $\mathrm{Cr}(\mathrm{VI})$ stress on phosphate-solubilizing bacteria (Bacillus sp. strain MRP-3): oxidative stress and bioaccumulation potential. Intl J Environ Res Public Health 16 (12). DOI: 10.3390/ijerph16122172.

Sharma S, Tiwari S, Hasan A, Saxena V, Pandey LM. 2018. Recent advances in conventional and contemporary methods for remediation of heavy metal-contaminated soils. 3 Biotech 8 (4): 216. DOI: 10.1007/s13205-018-1237-8.

Singh P, Kushwaha A, Hans N, Gautam A, Rani R. 2019. Evaluation of the cytotoxicity and interaction of lead with lead resistant bacterium Acinetobacter junii Pb1. Braz J Microbiol 50 (1): 223-230. DOI: 10.1007/s42770-019-00041-1.

Tiquia SM. 2018. Lead absorption mechanisms in bacteria as strategies for lead bioremediation. Appl Microbiol Biotechnol 102 (13): 5437-5444. DOI: 10.1007/s00253-018-8969-6.

Tripathi M, Munot HP, Shouche JMM, Goel R. 2005. Isolation and functional characterization of siderophore-producing lead- and cadmium-resistant Pseudomonas putida KNP9. Curr Microbiol 50 (5): 233-237. DOI: 10.1007/s00284-004-4459-4.

Vigneri R, Malandrino P, Gianì F, Russo M, Vigneri P. 2017. Heavy metals in the Volcanic Environment and Thyroid Cancer. Mol Cell Endocrinol 457: 73-80. DOI: 10.1016/j.mce.2016.10.027.

Villegas LC, Llamado AL, Catsao KV, Raymundo AK. 2018. Removal of heavy metals from aqueous solution by biofilm-forming bacteria isolated from mined-out soil in Mogpog, Marinduque, Philippines. Philipp Sci Lett 11.

Wang,X, Liu P, Liu F, Wang X, Ji M, Song L. 2018. Adsorption of Pb(II) by a polyvinylidene fluoride membrane bearing chelating poly (amino phosphonic acid) and poly(amino carboxylic acid) groups. Adsorp Sci Technol 36 (9-10): 1571-1594. DOI: 10.1177/0263617418795531.

Wani AL, Ara A, Usmani JA. 2015. Lead toxicity: a review. Interdiscip Toxicol 8 (2): 55-64. DOI: 10.1515/intox-2015-0009.

Yasawong M, Areekit S, Pakpitchareon A, Santiwatanakul S, Chansiri K. 2011. Characterization of thermophilic halotolerant Aeribacillus pallidus TD1 from Tao Dam Hot Spring, Thailand. Intl J Mol Sci 12 (8): 5294-5303. DOI: 10.3390/ijms12085294.

Yu S, Teng C, Bai X, Liang J, Song T, Dong L, Jin Y, Qu J. 2017. Optimization of siderophore production by Bacillus sp. PZ-1 and its potential enhancement of phytoextraction of $\mathrm{Pb}$ from Soil. $\mathrm{J}$ $\begin{array}{lllll}\text { Microbiol Biotechnol } 27 & (8) \text { : 1500-1512. DOI: }\end{array}$ 10.4014/jmb.1705.05021. 